On the Construction of Survivorship Assurance Tables. By Peter Gray, Esq., F.R.A.S.

[Read before the Institute, 26th April, 1852, and ordered by the Council to be printed.]

IN a Postscript to the introductory matter of the Assurance and Annuity Tables, compiled and published by Messrs. Smith, Orchard, and myself in April, 1851 (and which Postscript was written by me), it is stated that I had "devised a new table, which, while answering all, and more than all, the purposes of Tables V. and VI. [which show the single and annual premiums for a survivorship assurance of $\$ 1$ for every combination of two ages], by means of a single value for each pair of ages, and thus occupying little more space than one of them, would also be very much less laborious in its construction than the former of those tables. The new tables would, in fact, consist of series of columns supplementary to Mr. Jones's Commutation Tables for Two Lives, and possessing all the properties, mutatis mutandis, with respect to the formation of temporary and deferred, as well as present, whole life benefits and payments, that give to tables of the form of those mentioned their great value." The form of the table to which reference is here made suggested itself to me while occupied in superintending the printing of the work which contained the foregoing announcement. Having, however, had just then, as I thought, quite enough to do with survivorship assurances for a time, I contented myself with making the announcement cited, and communicating my ideas in a general way to my coadjutors, Messrs. Smith and Orchard.

My attention has recently been recalled to the subject-first, by a suggestion in the January Number of the Assurance Magazine that $I$ ought to make my method public, and, secondly, by the reading of a paper by Mr. David Chisholm, at the meeting of the Institute of Actuaries on the 23rd of February last, in which a method of constructing the same tables that $I$ had in view is very fully described and exemplified. Mr. Chisholm's paper appeared to me to be an exceedingly able one; and being occupied with a subject to which I had devoted great attention, I listened to the reading of it with much interest. In particular, I was gratified by the recognition, on the part of a gentleman of so much experience, of the value of, and the desirableness of possessing, tables of the kind I was the first to suggest. 
Mr. Chisholm's method of construction differs from mine. First, his method is essentially logarithmic, while mine admits of being applied both in numbers and in logarithms; and of the two modes $I$ think the former is the preferable. Again, $\mathrm{Mr}$. C.'s method is not continuous - that is, each tabular value is formed independently of other tabular values; and as a consequence, to ensure accuracy, either the whole work must be subjected to a rigid scrutiny, or the entire computation must be performed in duplicate. My method, on the other hand, in both its applications, is continuous. Fach succeeding value is deduced, by the simplest conceivable operation, from a preceding value, so that verification at a few points suffices to verify the whole. It seems to me, therefore, that it may not be unacceptable if I proceed now to explain and exemplify the method $I$ had in view. Those who may be disposed to undertake the improving exercise of forming the tables in question, will at all events have thus a choice of methods presented for their adoption.

It is known that

$$
\frac{1}{2}\left(p_{x, n-1}-p_{x, n}\right)\left(p_{y, n-1}+p_{y \cdot n}\right) v^{n},
$$

which may be also written thus,

$$
\frac{\frac{1}{2}\left(l_{x+n-1}-l_{x+n}\right)\left(l_{y+n-1}+l_{y+n}\right) v^{n}}{l_{x \cdot y}}
$$

denotes the present value of $£ 1$ to be received at the end of $n$ years, provided $(x)$ shall have died in the $n$th year, and $(y)$ have been alive at the instant of $(x)$ 's death. Now to adapt this expression to Mr. Jones's tables, we must introduce in both numerator and denominator such a power of $v$ as will make the latter equal to $\mathrm{D}_{x y y}$. This will be either $v^{x}$ or $v^{y}$, according as $x$ or $y$ is the greater. We shall thus have for the value of the contingency under consideration in the two cases--

$$
\begin{aligned}
& (x>y) \\
& (x<y) \\
& \frac{\frac{1}{2}\left(l_{x+n-1}-l_{x+n}\right)\left(l_{y+n-1}+l_{y+n}\right) v^{x+n}}{\mathrm{D}_{x . y}} ; \frac{\frac{1}{2}\left(l_{x+n-1}-l_{x+n}\right)\left(l_{y+n-1}+l_{y+n}\right) v^{y+n}}{\mathrm{D}_{x . y}} .
\end{aligned}
$$

The denominators of these expressions, as they now stand, being already formed (in Jones's tables), it is obvious that we have now to occupy ourselves with the formation of the numerators only, for the requisite number of cases of variation of $x, y$, and $n$.

Looking, then, at the numerators, involving three variables, $x, y$, and $n$, it might at first sight seem to be requisite to form 
them for every value of each of these quantities. But, in the first place, since of the two quantities $x$ and $y$, neither takes any values different from those taken by the other, and since in the first expression each value of $x$ is combined only with those values of $y$ that do not exceed it, and in the second each value of $y$ is combined only with those values of $\dot{x}$ that do not exceed it, it follows that the number of formations is thus at once reduced one half. And, in the second place, since, owing to the peculiar structure of the Commutation Tables, in both expressions the same effect is produced by any variation given to $n$ as by an equal variation given to both $x$ and $y$, it further follows, that it will suffice to compute the two expressions for all the values of $x$ and $y$, and for a single value of $n$.

It is most convenient to make $n=1$, in which case the numerators of the two expressions (which will then denote the value of the contingencies in respect of the first year) will respectively become

$$
\begin{array}{cc}
(x>y) & (x<y) \\
\frac{1}{2}\left(l_{x}-l_{x+1}\right)\left(l_{y}+l_{y+1}\right) v^{x+1}, \text { and } \frac{1}{2}\left(l_{x}-l_{x+1}\right)\left(l_{y}+l_{y+1}\right) v^{y+1} .
\end{array}
$$

And, in accordanee with what has just been said, the values of these expressions that will have to be computed, are (supposing the Carlisle Table to be used), of the first, those in which $x$ receives every value from 104 to 0 , and $y$ every value from $x$ to 0 ; and, of the second, those in which $y$ receives every value from 104 to 0 , and $x$ every value from $y$ to 0 . I proceed now to inquire how these values may be most advantageously formed.

The expressions deduced above will be simplified, if for $\frac{1}{2}\left(l_{x}-l_{x+1}\right)$ and $l_{y}+l_{y+1}$, we write $d_{x}$ and $s_{y}$ respectively. It might seem preferable to combine the constant factor $\frac{1}{2}$ with the quantity $l_{y}+l_{y+1}$, inasmuch as $d_{x}$ and $s_{y}$ would then denote, the former the number dying between the ages $x$ and $x+1$, and the latter the number living at age $y+\frac{1}{2}$. But the other arrangement will be found to be the more advantageous, since, the values of $l_{y}+l_{y+1}$ being generally very much greater than those of $l_{x}-l_{x+1}$, we are less inconvenienced, in the case of this latter function, by the additional figure which arises from the division of an odd number by 2. The expressions with which we have to deal will therefore now be denoted as follows:-

$$
\begin{array}{rrr}
(x>y) & (x<y) \\
d_{x} s_{y} y^{x+1} & \text { and } \quad d_{x} s_{y} y^{y+1} .
\end{array}
$$


The following table, formed from the Carlisle Table of Mortality by a process too obvious to need explanation, contains all the terms of the series $s_{y}$ and $d_{x}$, with their differences, for which we shall have occasion in the subsequent examples.

\begin{tabular}{|r|r|r|r|r|}
\hline$x \& y$ & \multicolumn{1}{|c|}{$s_{y}$} & \multicolumn{1}{|c|}{$\Delta s_{y}$} & \multicolumn{1}{|c|}{$d_{x}$} & \multicolumn{1}{c|}{$\Delta d_{x}$} \\
\hline 104 & & & \\
\hline 103 & 4 & 3 & $\cdot 5$ & $\cdot 5$ \\
102 & 8 & 4 & $1 \cdot 0$ & $\cdot 0$ \\
101 & 12 & 4 & $1 \cdot 0$ & $\cdot 0$ \\
100 & 16 & 4 & $1 \cdot 0$ & $\cdot 0$ \\
99 & 20 & 5 & $1 \cdot 0$ & $\cdot 0$ \\
98 & 25 & 7 & $1 \cdot 5$ & $\cdot 5$ \\
97 & 32 & 9 & $2 \cdot 0$ & $\cdot 5$ \\
96 & 41 & 12 & $2 \cdot 5$ & $1 \cdot 0$ \\
95 & 53 & 17 & $3 \cdot 5$ & $1 \cdot 5$ \\
94 & 70 & 24 & $5 \cdot 0$ & $2 \cdot 0$ \\
93 & 94 & 35 & $7 \cdot 0$ & $3 \cdot 5$ \\
92 & 129 & 51 & $10 \cdot 5$ & $4 \cdot 5$ \\
91 & 180 & 67 & $15 \cdot 0$ & $3 \cdot 5$ \\
90 & 247 & 76 & $18 \cdot 5$ & $1 \cdot 0$ \\
89 & 323 & 90 & $19 \cdot 5$ & $6 \cdot 0$ \\
88 & 413 & 115 & $25 \cdot 5$ & $6 \cdot 5$ \\
87 & 528 & 135 & $32 \cdot 0$ & $3 \cdot 5$ \\
86 & 663 & 149 & $35 \cdot 5$ & $3 \cdot 5$ \\
85 & 812 & 162 & $39 \cdot 0$ & $3 \cdot 0$ \\
84 & 974 & 178 & $42 \cdot 0$ & $5 \cdot 0$ \\
83 & 1152 & 196 & $47 \cdot 0$ & $4 \cdot 0$ \\
82 & 1348 & & $51 \cdot 0$ & \\
\hline
\end{tabular}

At this point the two methods which I propose to develope part company, and must henceforth be treated separately. I therefore commence with-

\section{I.-The Construction in Numbers.}

The process is to be continuous. To see, therefore, how succeeding values can be most readily deduced from each other, taking first the case $x>y$, write down in order a few of the leading terms of the series belonging to adjoining differences of age, thus :--

$$
\begin{array}{llll}
x-y=0 & x-y=1 & x-y=2 & x-y=3 \\
d_{104} s_{104} v^{105} & d_{104} s_{103} v^{105} & d_{104} s_{102} v^{10 \overline{5}} & d_{104} s_{101} v^{105} \\
d_{103} s_{103} v^{104} & d_{103} s_{102} v^{104} & d_{103} s_{101} v^{104} & d_{103} s_{100} v^{104} \\
d_{102} s_{102} v^{303} & d_{102 s_{101}} v^{103} & d_{102} s_{100} v^{103} & d_{102} s_{99} v^{103}
\end{array}
$$

and so on. Now what we have to ascertain is, how we can most easily pass from any one term to an adjoining term. Fxamine, then, the succession of values in the several columns. We see that in passing from term to term all the three factors vary; the 
addends consequently would obviously be characterized by a degree of complexity that would quite unfit them for our purpose. But examine the succession in the several rows. Here we see that only one factor varies in passing from term to term; and that the terms consequently are nothing else than a series of multiples by this varying factor of the constant product of the two remaining factors. Farther, the differences of these terms will also be a series of multiples of the same constant product; so that, if this last series be formed, we shall be able, by continuous addition of its terms to the initial value, namely, that corresponding to $x-y=0$, to form, with great facility, the terms belonging to each row.

To make this more plain, denote for a moment $d_{104} v^{105}, d_{103} v^{104}$, $d_{102} v^{103}$, \&c., by $P, Q, R, \& c .$, respectively; then will the abovewritten terms take the following form:-

$\begin{array}{cccc}x-y=0 & x-y=1 & x-y=2 & x-y=3 \\ \mathrm{P} s_{104} & \mathrm{P} s_{103} & \mathrm{P} s_{102} & \mathrm{P} s_{101} \\ \mathrm{Q} s_{103} & \mathrm{Q} s_{102} & \mathrm{Q} s_{101} & \mathrm{Q} s_{100} \\ \mathrm{R} s_{102} & \mathrm{R} s_{101} & \mathrm{R} s_{100} & \mathrm{R} s_{99}\end{array}$

and so on. And their differences, taken from the several rows, will be

$$
\begin{array}{lll}
\mathrm{P}\left(s_{103}-s_{100}\right), & \mathrm{P}\left(s_{102}-s_{103}\right), & \mathrm{P}\left(s_{101}-s_{102}\right), \\
\mathrm{Q}\left(s_{102}-s_{103}\right), & \mathrm{Q}\left(s_{101}-s_{102}\right), & \mathrm{Q}\left(s_{100}-s_{101}\right), \\
\mathrm{R}\left(s_{101}-s_{102}\right), & \mathrm{R}\left(s_{100}-s_{101}\right), & \mathrm{R}\left(s_{99}-s_{100}\right) ;
\end{array}
$$

or,

$\begin{array}{lll}\mathrm{P} \Delta s_{1093}, & \mathrm{P} \Delta s_{113,}, & \mathrm{P} \Delta s_{102,}, \\ \mathrm{Q} \Delta s_{103}, & \mathrm{Q} \Delta s_{109,}, & \mathrm{Q} \Delta s_{1019}, \\ \mathrm{R} \Delta s_{1023} & \mathrm{R} \Delta s_{1613}, & \mathrm{R} \Delta s_{1100} .\end{array}$

It thus appears that the values occupying the first row in the foregoing scheme will be formed by the continuous addition to the initial term, $P s_{104}$ of the products of the quantity $\mathrm{P}$ (or $d_{104} v^{105}$ ), by the successive terms of the series $\Delta s_{y}$, which is one of those of which a portion is tabulated on page 110. In like manner, the values occupying the second row will be formed by the continuous addition to its initial term, $\mathrm{Q} s_{103}$, of the products of the quantity $\mathrm{Q}$ (or $d_{103} v^{104}$ ), by the successive terms of the same series $\Delta s_{y}$; and so also for the third and following rows.

A like property holds with respect to the function belonging to the case $x \angle y$, as may be very briefly shown. 


$$
x>y
$$

\begin{tabular}{|c|c|c|c|c|c|c|}
\hline$x-y$ & $s_{y}$ & $x=104$ & $x=103$ & $x=102$ & $x=101$ & $x=100$ \\
\hline 0 & $\begin{array}{l}1 \\
3\end{array}$ & $\begin{array}{r}0224420 \\
673260\end{array}$ & $\begin{array}{l}\cdot 1849220 \\
\cdot 1849220\end{array}$ & $\begin{array}{l}\cdot 3809394 \\
\cdot 1904697\end{array}$ & $\begin{array}{l}\cdot 5885513 \\
\cdot 1961838\end{array}$ & $\begin{array}{l}\cdot 8082771 \\
\cdot 2020693\end{array}$ \\
\hline 1 & $\begin{array}{l}4 \\
4\end{array}$ & $\begin{array}{r}.0897680 \\
897680\end{array}$ & $\begin{array}{l}\cdot 3698440 \\
\cdot 1849220\end{array}$ & $\begin{array}{l}\cdot 5714091 \\
\cdot 1904697\end{array}$ & $\begin{array}{l}7847351 \\
.1961838\end{array}$ & $\begin{array}{r}1.0103464 \\
2525866\end{array}$ \\
\hline 2 & $\begin{array}{l}8 \\
4 \\
\end{array}$ & $\begin{array}{r}1795360 \\
897680\end{array}$ & $\begin{array}{l}-5547660 \\
-1849220\end{array}$ & $\begin{array}{l}.7618788 \\
.1904697\end{array}$ & $\begin{array}{l}-9809189 \\
-2452297\end{array}$ & $\begin{array}{r}12629330 \\
3536212 \\
\end{array}$ \\
\hline$\overline{3}$ & $\begin{array}{r}12 \\
4\end{array}$ & $\begin{array}{r}2693040 \\
897680\end{array}$ & $\begin{array}{l}7396880 \\
.1849220\end{array}$ & $\begin{array}{l}\cdot 9523485 \\
2380871\end{array}$ & $\begin{array}{r}1 \cdot 2261486 \\
3433216\end{array}$ & $\begin{array}{r}16165542 \\
\cdot 4546559\end{array}$ \\
\hline 4 & $\begin{array}{r}16 \\
4\end{array}$ & $\begin{array}{r}3590720 \\
897680\end{array}$ & $\begin{array}{l}-9246100 \\
-2311525\end{array}$ & $\begin{array}{r}11904356 \\
3333219 \\
\end{array}$ & $\begin{array}{r}1.5694702 \\
\cdot 4414135 \\
\end{array}$ & $\begin{array}{r}20712101 \\
.6062078 \\
\end{array}$ \\
\hline 5 & $\begin{array}{r}20 \\
5 \\
\end{array}$ & 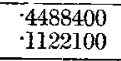 & $\begin{array}{r}1 \cdot 1557625 \\
3236135 \\
\end{array}$ & $\begin{array}{r}15237575 \\
.4285568 \\
\end{array}$ & $\begin{array}{r}20108837 \\
.5885513 \\
\end{array}$ & $\begin{array}{r}26774179 \\
85587944 \\
\end{array}$ \\
\hline 6 & $\begin{array}{r}25 \\
7 \\
\end{array}$ & $\begin{array}{l}.5610500 \\
.1570939\end{array}$ & $\begin{array}{r}1.4793760 \\
4160745\end{array}$ & $\begin{array}{r}19523143 \\
5714090 \\
\end{array}$ & $\begin{array}{r}25994350 \\
-8337810 \\
\end{array}$ & $\begin{array}{l}35362123 \\
1-2124157 \\
\end{array}$ \\
\hline 7 & $\begin{array}{r}32 \\
9 \\
\end{array}$ & $\begin{array}{l}7181439 \\
2019779\end{array}$ & $\begin{array}{r}18954505 \\
5547661 \\
\end{array}$ & $\begin{array}{r}25237233 \\
-8094961 \\
\end{array}$ & $\begin{array}{l}34332160 \\
1 \cdot 1771026\end{array}$ & $\begin{array}{l}47486280 \\
17681062 \\
\end{array}$ \\
\hline 8 & $\begin{array}{l}41 \\
12\end{array}$ & $\begin{array}{l}\cdot 9201218 \\
\cdot 2693039\end{array}$ & $\begin{array}{r}24502166 \\
7859186 \\
\end{array}$ & $\begin{array}{l}33332194 \\
11428181\end{array}$ & $\begin{array}{l}46103186 \\
17166080\end{array}$ & $\begin{array}{l}6.5167342 \\
25763833\end{array}$ \\
\hline 9 & $\begin{array}{l}53 \\
17 \\
\end{array}$ & $\begin{array}{r}1 \cdot 1894257 \\
3815139 \\
\end{array}$ & $\begin{array}{l}32361352 \\
11095321 \\
\end{array}$ & $\begin{array}{l}44760375 \\
16666097\end{array}$ & $\begin{array}{l}63269266 \\
25013430 \\
\end{array}$ & $\begin{array}{l}90931175 \\
33846604 \\
\end{array}$ \\
\hline 10 & $\begin{array}{l}70 \\
24\end{array}$ & $\begin{array}{r}1.5709396 \\
5386078\end{array}$ & $\begin{array}{l}43456673 \\
1 \cdot 6180677\end{array}$ & $\begin{array}{l}61426472 \\
24284884\end{array}$ & $\begin{array}{l}8828 \% 096 \\
32860781\end{array}$ & $\begin{array}{r}1247777799 \\
38393163 \\
\end{array}$ \\
\hline 11 & $\begin{array}{l}94 \\
35 \\
\end{array}$ & $\begin{array}{r}210954 \overline{74} \\
7854697 \\
\end{array}$ & $\begin{array}{l}5.9637350 \\
23577557\end{array}$ & $\begin{array}{l}85711356 \\
31903671 \\
\end{array}$ & $\begin{array}{r}121143477 \\
37274916 \\
\end{array}$ & $\begin{array}{r}163170942 \\
45465588 \\
\end{array}$ \\
\hline 12 & $\begin{array}{r}129 \\
51 \\
\end{array}$ & $\begin{array}{l}28950171 \\
1 \cdot 1445416\end{array}$ & $\begin{array}{l}83214907 \\
30974438\end{array}$ & $\begin{array}{r}117615027 \\
36189239\end{array}$ & $\begin{array}{r}158418393 \\
4.4141348\end{array}$ & $\begin{array}{r}208636530 \\
5.8094918\end{array}$ \\
\hline 13 & 180 & 40395587 & 114189345 & 153804266 & 202559741 & 266731448 \\
\hline
\end{tabular}

$x \angle y$

\begin{tabular}{|c|c|c|c|c|c|c|}
\hline$y-x$ & $d_{x}$ & $y=104$ & $y=103$ & $y=102$ & $y=101$ & $y=100$ \\
\hline 0 & $\begin{array}{l}.5 \\
.5\end{array}$ & $\begin{array}{r}-0224420 \\
224420\end{array}$ & $\begin{array}{r}1849220 \\
0\end{array}$ & $\begin{array}{r}\cdot 3809394 \\
0\end{array}$ & $\begin{array}{r}5885513 \\
0\end{array}$ & $\begin{array}{r}8082771 \\
0\end{array}$ \\
\hline 1 & $\begin{array}{r}10 \\
.0 \\
\end{array}$ & $\begin{array}{r}0448840 \\
0\end{array}$ & $\begin{array}{r}1849220 \\
0\end{array}$ & $\begin{array}{r}3809594 \\
0 \\
\end{array}$ & $\begin{array}{r}5885513 \\
0 \\
\end{array}$ & $\begin{array}{l}-8082771 \\
.4041386\end{array}$ \\
\hline 2 & $\begin{array}{r}1.0 \\
\cdot 0\end{array}$ & $\begin{array}{r}.0448840 \\
0\end{array}$ & $\begin{array}{r}.1849220 \\
0\end{array}$ & $\begin{array}{r}.3809394 \\
0\end{array}$ & $\begin{array}{l}-5885513 \\
.2942757\end{array}$ & $\begin{array}{r}1.2124157 \\
\cdot 4041386\end{array}$ \\
\hline 3 & $\begin{array}{r}10 \\
.0\end{array}$ & $\begin{array}{r}0448840 \\
0\end{array}$ & $\begin{array}{r}\cdot 1849220 \\
0\end{array}$ & $\begin{array}{l}\cdot 3809394 \\
-1904697\end{array}$ & $\begin{array}{l}8828270 \\
-2942757\end{array}$ & $\begin{array}{r}1 \cdot 6165543 \\
\cdot 4041386\end{array}$ \\
\hline 4 & $\begin{array}{r}1.0 \\
.0\end{array}$ & $\begin{array}{r}.0448840 \\
0\end{array}$ & $\begin{array}{r}-1849220 \\
924610\end{array}$ & $\begin{array}{l}\cdot 5714091 \\
\cdot 1904697\end{array}$ & $\begin{array}{r}1 \cdot \overline{1771027} \\
.2942757\end{array}$ & $\begin{array}{r}20206929 \\
.8082771\end{array}$ \\
\hline 5 & $\begin{array}{r}1.0 \\
-5\end{array}$ & $\begin{array}{r}0448840 \\
224490 \\
\end{array}$ & $\begin{array}{r}.2773830 \\
924610 \\
\end{array}$ & $\begin{array}{l}.7618788 \\
.1904697 \\
\end{array}$ & $\begin{array}{r}14713784 \\
.5885513 \\
\end{array}$ & $\begin{array}{l}28289700 \\
1.2124157\end{array}$ \\
\hline 6 & $\begin{array}{r}1.5 \\
.5\end{array}$ & $\begin{array}{r}0673260 \\
224420\end{array}$ & $\begin{array}{r}3698440 \\
924610\end{array}$ & $\begin{array}{r}9523485 \\
.3809394\end{array}$ & $\begin{array}{r}20599297 \\
8828270\end{array}$ & $\begin{array}{l}40413857 \\
1.6165543\end{array}$ \\
\hline 7 & $\begin{array}{r}20 \\
5 \\
\end{array}$ & $\begin{array}{r}0897680 \\
224420 \\
\end{array}$ & $\begin{array}{l}-4623050 \\
.1849220 \\
\end{array}$ & $\begin{array}{r}13332879 \\
.5714090\end{array}$ & $\begin{array}{l}29427567 \\
1.1771026 \\
\end{array}$ & $\begin{array}{l}56579400 \\
28289699\end{array}$ \\
\hline 8 & $\begin{array}{l}25 \\
10 \\
\end{array}$ & $\begin{array}{r}-1122100 \\
448840\end{array}$ & $\begin{array}{l}-6472270 \\
.2773830\end{array}$ & $\begin{array}{r}19046969 \\
.7618787\end{array}$ & $\begin{array}{l}4-1198593 \\
20599296\end{array}$ & $\begin{array}{l}84869099 \\
36372471\end{array}$ \\
\hline 9 & $\begin{array}{l}3.5 \\
15 \\
\end{array}$ & $\begin{array}{r}-1570940 \\
673260 \\
\end{array}$ & $\begin{array}{l}-9246100 \\
-3698440 \\
\end{array}$ & $\begin{array}{l}26665756 \\
1.3332877\end{array}$ & $\begin{array}{l}61797889 \\
26484809\end{array}$ & $\begin{array}{r}12 \cdot 1241570 \\
2 \cdot 8289699\end{array}$ \\
\hline 10 & $\begin{array}{l}50 \\
20 \\
\end{array}$ & $\begin{array}{r}.2244200 \\
897630 \\
\end{array}$ & $\begin{array}{r}1.2944540 \\
.6472271 \\
\end{array}$ & $\begin{array}{l}3.9998638 \\
1.7142271 \\
\end{array}$ & $\begin{array}{l}88282698 \\
20599296 \\
\end{array}$ & $\begin{array}{r}149531269 \\
\quad 8082771\end{array}$ \\
\hline 11 & $\begin{array}{l}70 \\
35 \\
\end{array}$ & $\begin{array}{l}-3141880 \\
.1570940\end{array}$ & $\begin{array}{r}19416811 \\
.8321491 \\
\end{array}$ & $\begin{array}{l}57140904 \\
13332877 \\
\end{array}$ & $\begin{array}{r}1088881994 \\
5885513 \\
\end{array}$ & $\begin{array}{r}15 \cdot 7614040 \\
48496627\end{array}$ \\
\hline 12 & $\begin{array}{r}105 \\
45 \\
\end{array}$ & $\begin{array}{l}.4712820 \\
.2019779\end{array}$ & $\begin{array}{r}27738302 \\
+6472271 \\
\end{array}$ & $\begin{array}{r}70473781 \\
-3809394 \\
\end{array}$ & $\begin{array}{r}11-4767507 \\
35313078 \\
\end{array}$ & $\begin{array}{r}206110667 \\
52538013\end{array}$ \\
\hline 13 & 150 & .6732599 & 34210573 & 74283175 & 150080585 & 258648680 \\
\hline
\end{tabular}


1855.] Construction of Survivorship Assurance Tables.

$x>y$

\begin{tabular}{|c|c|c|c|c|c|c|}
\hline$x-y$ & $s_{y}$ & $x=99$ & $x=98$ & $x=97$ & $x==96$ & $x=95$ \\
\hline 0 & $\begin{array}{r}20 \\
5\end{array}$ & $\begin{array}{r}1 \cdot 0406568 \\
\cdot 2601642\end{array}$ & $\begin{array}{r}20097684 \\
\cdot 5627352\end{array}$ & $\begin{array}{r}35329050 \\
.9936295\end{array}$ & $\begin{array}{l}58279131 \\
1 \cdot 7057307\end{array}$ & $\begin{array}{r}108635143 \\
34845235\end{array}$ \\
\hline 1 & $\begin{array}{r}25 \\
7\end{array}$ & $\begin{array}{r}13008210 \\
.3642299\end{array}$ & $\begin{array}{r}25725036 \\
7235166\end{array}$ & $\begin{array}{l}45265345 \\
1.3248394\end{array}$ & $\begin{array}{l}75336438 \\
244164518\end{array}$ & $\begin{array}{r}143480378 \\
49193273\end{array}$ \\
\hline 2 & $\begin{array}{r}32 \\
9\end{array}$ & $\begin{array}{r}16650509 \\
\cdot 4682956\end{array}$ & $\begin{array}{r}960202 \\
9646889\end{array}$ & $\begin{array}{l}58513739 \\
18768558\end{array}$ & $\begin{array}{l}99500956 \\
34114613\end{array}$ & $\begin{array}{r}192673651 \\
7.1740189\end{array}$ \\
\hline 3 & $\begin{array}{l}41 \\
12\end{array}$ & $\begin{array}{r}21333465 \\
6243941\end{array}$ & $\begin{array}{l}4 \cdot 2607091 \\
1 \cdot 3666425\end{array}$ & $\begin{array}{l}77282297 \\
2 \cdot 6496787\end{array}$ & $\begin{array}{r}133615569 \\
49750478\end{array}$ & $\begin{array}{l}26 . \overline{4413840} \\
104535704\end{array}$ \\
\hline 4 & $\begin{array}{l}53 \\
17\end{array}$ & $\begin{array}{r}27577406 \\
.8845583\end{array}$ & $\begin{array}{l}56273516 \\
1.9293777\end{array}$ & $\begin{array}{r}103779084 \\
38641148\end{array}$ & $\begin{array}{r}18 \cdot 3366047 \\
7 \cdot 2493553\end{array}$ & $\begin{array}{l}368949544 \\
137331219\end{array}$ \\
\hline 5 & $\begin{array}{l}70 \\
24\end{array}$ & $\begin{array}{l}3 \cdot 6422989 \\
1 \cdot 2487882\end{array}$ & $\begin{array}{l}75567293 \\
28136758\end{array}$ & $\begin{array}{r}14 \cdot 2420232 \\
5 \cdot 6305673\end{array}$ & $\begin{array}{r}2558556000 \\
9 \cdot 5236629\end{array}$ & $\begin{array}{l}506: 80763 \\
155778696\end{array}$ \\
\hline 6 & $\begin{array}{l}94 \\
35\end{array}$ & $\begin{array}{l}48910871 \\
18211494\end{array}$ & $\begin{array}{r}103704051 \\
40999276\end{array}$ & $\begin{array}{r}19 \cdot 8725905 \\
7.3970198\end{array}$ & $\begin{array}{l}351096229 \\
108029609\end{array}$ & $\begin{array}{r}66-2059459 \\
18-4474772\end{array}$ \\
\hline 7 & $\begin{array}{r}129 \\
51\end{array}$ & $\begin{array}{l}677122365 \\
26536748\end{array}$ & $\begin{array}{r}144703327 \\
5.3861794\end{array}$ & $\begin{array}{r}27 \cdot 2696103 \\
83906493\end{array}$ & $\begin{array}{l}45 \cdot 9125838 \\
12 \cdot 7929800\end{array}$ & $\begin{array}{l}846534231 \\
235717764\end{array}$ \\
\hline 8 & $\begin{array}{r}180 \\
67\end{array}$ & $\begin{array}{l}93659113 \\
3 \cdot 4862003\end{array}$ & $\begin{array}{r}198565121 \\
61096961\end{array}$ & $\begin{array}{r}56602596 \\
9.9362952\end{array}$ & $\begin{array}{l}587055638 \\
163465856\end{array}$ & $\begin{array}{r}1082251995 \\
27-6712158\end{array}$ \\
\hline 9 & $\begin{array}{r}247 \\
76\end{array}$ & $\begin{array}{r}128521116 \\
39544958\end{array}$ & $\begin{array}{r}259662082 \\
7.2351664\end{array}$ & $\begin{array}{l}45.5965548 \\
126963772\end{array}$ & $\begin{array}{l}75 \cdot 0 \overline{2} 1494 \\
19 \cdot 1894700\end{array}$ & $\begin{array}{r}1358964153 \\
305408234\end{array}$ \\
\hline 10 & $\begin{array}{r}3223 \\
90\end{array}$ & $\begin{array}{r}16.8066074 \\
46829556\end{array}$ & $\begin{array}{r}332013746 \\
92449348\end{array}$ & $\begin{array}{l}582929320 \\
14.9044428\end{array}$ & $\begin{array}{l}94 \cdot 2416194 \\
211794892\end{array}$ & $\begin{array}{r}166.4372387 \\
332054589\end{array}$ \\
\hline 11 & $\begin{array}{l}413 \\
115\end{array}$ & $\begin{array}{r}214895830 \\
59837766\end{array}$ & $\begin{array}{l}42 \cdot 4463094 \\
108527496\end{array}$ & $\begin{array}{l}731973748 \\
164500887\end{array}$ & $\begin{array}{r}1154211086 \\
230273640\end{array}$ & $\begin{array}{r}1996426976 \\
364850104\end{array}$ \\
\hline 12 & $\begin{array}{l}528 \\
135\end{array}$ & $\begin{array}{r}274733896 \\
70244334\end{array}$ & $\begin{array}{l}53 \cdot 2990590 \\
119782199\end{array}$ & $\begin{array}{l}896474635 \\
178853313\end{array}$ & $\begin{array}{r}138.4484726 \\
25.3016716\end{array}$ & $\begin{array}{r}2361277080 \\
401745059\end{array}$ \\
\hline 13 & $\overline{663}$ & 344977730 & 652772789 & 1075327948 & 1687501442 & 2763022139 \\
\hline
\end{tabular}

$x<y$

\begin{tabular}{|c|c|c|c|c|c|c|}
\hline$y-x$ & $d_{x}$ & $y=99$ & $y=98$ & $y=97$ & $y=96$ & $y=95$ \\
\hline 0 & $\begin{array}{r}1.0 \\
\cdot 5 \\
\end{array}$ & $\begin{array}{r}1 \cdot 0406568 \\
\cdot 5203284 \\
\end{array}$ & $\begin{array}{r}20097684 \\
-6699228\end{array}$ & $\begin{array}{r}3-5329050 \\
-8832262 \\
\end{array}$ & $\begin{array}{l}58279131 \\
23311652 \\
\end{array}$ & $\begin{array}{r}108685143 \\
46557919\end{array}$ \\
\hline I & $\begin{array}{r}1 \cdot 5 \\
\cdot 5 \\
\end{array}$ & $\begin{array}{r}1.5609852 \\
5203284 \\
\end{array}$ & $\begin{array}{r}26796912 \\
\quad 6699228\end{array}$ & $\begin{array}{l}44161312 \\
17664525\end{array}$ & $\begin{array}{l}8.1590783 \\
3.4967479\end{array}$ & $\begin{array}{r}155193062 \\
62077225\end{array}$ \\
\hline 2 & $\begin{array}{r}20 \\
-5\end{array}$ & $\begin{array}{r}20813136 \\
5203284\end{array}$ & $\begin{array}{l}33496140 \\
13398456\end{array}$ & $\begin{array}{l}61825837 \\
26496787\end{array}$ & $\begin{array}{r}116558262 \\
46623305\end{array}$ & $\begin{array}{l}217270287 \\
108635144\end{array}$ \\
\hline $\mathbf{3}$ & $\begin{array}{l}25 \\
1.0\end{array}$ & $\begin{array}{l}26016420 \\
1.0406568\end{array}$ & $\begin{array}{l}46894596 \\
20097684\end{array}$ & $\begin{array}{l}88322624 \\
35329050\end{array}$ & $\begin{array}{r}163181567 \\
81590784\end{array}$ & $\begin{array}{l}325905451 \\
139673756\end{array}$ \\
\hline 4 & $\begin{array}{l}35 \\
1.5 \\
\end{array}$ & $\begin{array}{l}3.6422988 \\
15609852\end{array}$ & $\begin{array}{l}6 \cdot 6992280 \\
26796913\end{array}$ & $\begin{array}{r}1236 \overline{651674} \\
61825837 \\
\end{array}$ & $\begin{array}{l}244772351 \\
104902436\end{array}$ & $\begin{array}{l}465579187 \\
10^{\circ} 8635144\end{array}$ \\
\hline 5 & $\begin{array}{l}50 \\
20\end{array}$ & $\begin{array}{l}22032840 \\
20813136\end{array}$ & $\begin{array}{l}9 \cdot 3789193 \\
46894597\end{array}$ & $\begin{array}{r}185477511 \\
79490361 \\
\end{array}$ & $\begin{array}{r}349674787 \\
81590784\end{array}$ & $\begin{array}{r}574214381 \\
3-1038612\end{array}$ \\
\hline 6 & $\begin{array}{l}70 \\
35 \\
5\end{array}$ & $\begin{array}{l}7 \cdot 2845976 \\
36422988\end{array}$ & $\begin{array}{r}140683790 \\
60293053\end{array}$ & $\begin{array}{r}204967872 \\
6.1825837 \\
\end{array}$ & $\begin{array}{r}431265571 \\
23311652\end{array}$ & $\begin{array}{l}605259943 \\
186231675\end{array}$ \\
\hline 7 & $\begin{array}{r}105 \\
45\end{array}$ & $\begin{array}{r}109268964 \\
46829556\end{array}$ & $\begin{array}{r}200976843 \\
46894597\end{array}$ & $\begin{array}{r}326793709 \\
17664525\end{array}$ & $\begin{array}{l}45 \cdot 4577223 \\
139869915\end{array}$ & $\begin{array}{l}791484618 \\
201750981\end{array}$ \\
\hline 8 & $\begin{array}{r}150 \\
35\end{array}$ & $\begin{array}{r}156098520 \\
36422988\end{array}$ & $\begin{array}{r}247871440 \\
13398456\end{array}$ & $\begin{array}{l}344458234 \\
105987148\end{array}$ & $\begin{array}{l}59 \cdot 4447138 \\
15 \cdot 1525741\end{array}$ & $\begin{array}{l}993235599 \\
108635144\end{array}$ \\
\hline 9 & $\begin{array}{r}185 \\
1.0\end{array}$ & $\begin{array}{r}19 \cdot 252 \overline{1508} \\
1-0406568\end{array}$ & $\begin{array}{r}261269896 \\
80390738\end{array}$ & $\begin{array}{l}450445382 \\
11.4819411\end{array}$ & $\begin{array}{r}745972879 \\
81590784\end{array}$ & $\begin{array}{r}1101870743 \\
108635144\end{array}$ \\
\hline 10 & $\begin{array}{r}195 \\
60 \\
\end{array}$ & $\begin{array}{r}202928076 \\
62439408 \\
\end{array}$ & $\begin{array}{r}34 \cdot 1660634 \\
87089966\end{array}$ & $\begin{array}{r}565264793 \\
6.1825837 \\
\end{array}$ & $\begin{array}{r}827500663 \\
81590784\end{array}$ & $\begin{array}{r}121 \cdot 0505887 \\
93115837\end{array}$ \\
\hline 11 & $\begin{array}{r}255 \\
65 \\
\end{array}$ & $\begin{array}{r}26.5367484 \\
67642692 \\
\end{array}$ & $\begin{array}{r}428750600 \\
468894597 \\
\end{array}$ & $\begin{array}{r}627090630 \\
6.1825837 \\
\end{array}$ & $\begin{array}{r}909154447 \\
69934957\end{array}$ & $\begin{array}{r}1303621724 \\
155193062\end{array}$ \\
\hline 12 & $\begin{array}{r}320 \\
35\end{array}$ & $\begin{array}{r}33 \cdot 3010176 \\
36422988\end{array}$ & $\begin{array}{r}475645197 \\
46894597\end{array}$ & $\begin{array}{r}68.8916467 \\
5-2993574\end{array}$ & $\begin{array}{l}979089404 \\
116558263\end{array}$ & $\begin{array}{r}1458814786 \\
124154450\end{array}$ \\
\hline 13 & 355 & 36.9433164 & 522539794 & 741910041 & 1095647667 & $\overline{1582969236}$ \\
\hline
\end{tabular}




$$
\begin{array}{llll}
y-x=0 & y-x=1 & y-x=2 & y-x=3 \\
d_{104} s_{104} v^{195}, & d_{103} s_{104} v^{105}, & d_{102} s_{104} v^{105}, & d_{101} s_{104} v^{105}, \\
d_{103} s_{102} v^{104}, & d_{102} s_{103} v^{104}, & d_{301} s_{103} v^{104}, & d_{100} s_{103} v^{104}, \\
d_{102} s_{102} v^{103} & d_{103} s_{102} v^{103}, & d_{100} s_{102} v^{103}, & d_{99} s_{102} v^{103},
\end{array}
$$

and so on. Calling for a moment $s_{104} v^{105}, s_{103} v^{104}, s_{102} v^{103}$, \&c., $\mathrm{P}^{\prime}, \mathrm{Q}^{\prime}, \mathbf{R}^{\prime}$, \&c. respectively, the foregoing terms may be written thus :-

$\begin{array}{llll}\mathrm{P}^{\prime} d_{104}, & \mathrm{P}^{\prime} d_{103,}, & \mathrm{P}^{\prime} d_{102,}, & \mathrm{P}^{\prime} d_{101,} \\ \mathrm{Q}^{\prime} d_{103,} & \mathrm{Q}^{\prime} d_{102}, & \mathrm{Q}^{\prime} d_{101,}, & \mathrm{Q}^{\prime} d_{1009} \\ \mathrm{R}^{\prime} d_{102}, & \mathrm{R}^{\prime} d_{101}, & \mathrm{R} d_{100,} & \mathrm{R}^{\prime} d_{99} ;\end{array}$

and their differences, taken from the rows, will be

$$
\begin{array}{lll}
\mathrm{P}^{\prime} \Delta d_{104}, & \mathrm{P}^{\prime} \Delta d_{103,}, & \mathrm{P}^{\prime} \Delta d_{102,}, \\
\mathrm{Q} \Delta d_{103,} & \mathrm{Q}^{\prime} \Delta d_{102,}, & \mathrm{Q}^{\prime} \Delta d_{101}, \\
\mathrm{R}^{\prime} \Delta d_{102}, & \mathrm{R}^{\prime} \Delta d_{101}, & \mathrm{R}^{\prime} \Delta d_{100}
\end{array}
$$

The operation here, then, it thus appears, will be altogether analogous to that in the former case. The terms in the several rows, being multiples of the quantities $\mathrm{P}^{\prime}, \mathrm{Q}^{\prime}, \mathbf{R}^{\prime}$, \&c. respectively, will be formed by the continuous addition to an initial term of series of multiples of the same quantities, by the successive values of $\Delta d_{x}$, which also is a tabulated series.

The preceding example (pages 6 and 7) shows the practical application of the foregoing precepts, the rate of interest being 3 per cent.

The example consists of two portions, corresponding to the relative magnitudes of $x$ and $y, x$ being greater than $y$ in the former, and less than $y$ in the latter. In the first portion, $x$ is constant in each column, and decreases by a unit in passing from column to column. On the other hand, $y$ is equal to $x$ in the first row, and decreases by a unit in descending from each row to the next. As a consequence, the relation between $x$ and $y$ in each row is that indicated by the values in the column headed $x-y$. Thus, in the first row, proceeding from left to right, we have the values of the function corresponding to $x=104, y=104 ; x=103$, $y=103$, and so on; in the second row we have the values corresponding to $x=104, y=103 ; x=103, y=102$; and so of the succeeding rows. The column headed $s_{y}$, which is supposed to be written on a separate piece of paper or card, and consequently to be moveable, contains the successive values of $s_{y}$, taken from the table on page 110, with their differences, i.e., the values of $\Delta s_{y}$, on alter- 
nate lines. In the present position of this slip the values upon it have, opposite to each, in the column headed 104, the multiple by that value of the quantity we have called $P$, namely, $d_{104} v^{v^{05}}$, it being understood that the initial value and the multiples corresponding to the values of $\Delta s_{y}$ only have been independently formed, continuous addition of these giving the multiples corresponding to the values of $s_{y}$, the accuracy of which there is consequently the power of determining at any point. If the slip be now conceived to be moved up one step, and so applied to the column headed 103, the same thing will hold. Each value on the slip will have opposite to it in this column the multiple of the quantity called $\mathrm{Q}$, namely, $d_{103} v^{104}$, corresponding to that value; of which multiples, as before, the initial value and those corresponding to the successive values of $\Delta s_{y}$ only have been independently formed, the others being derived from these by continuous addition. It will thus be understood, that in passing from each column to the next the slip has to be moved up one step, and in the position thus attained it will indicate the multiples to be inserted in the adjoining column. A second representation of it is introduced, in connection with the column headed 99 , to show the position it will have assumed when the first five columns have been passed over.

The foregoing description applies, with but little change, to the remaining portion of the example. In regard to variation in passing from column to column and from row to row, $y$ here takes the place of $x$ in the former portion; and generally it will be found that in corresponding values the values of $x$ and $y$ are merely interchanged. The moveable slip here contains the successive values of $d_{x}$ and their differences, and the multiples in the several columns are those of the quantities $\mathbf{P}^{\prime}, \mathbf{Q}^{\prime}, \mathrm{R}^{\prime}$, \&c. Here, too, the slip is shown in two different positions.

It seems hardly necessary to remark, that each portion of the computation will consist of 105 columns and 105 rows, and that each column, in passing from left to right, and each row in passing from upper to lower, will contain one value fewer than the preceding; so that both the last column and the last row will contain each but a single value.

It remains to describe the method of forming the addends, which, as has been shown, consist of a series of multiples of a quantity, which is the same for each column, but different for different columns, the multipliers being in the one case $(x>y)$, 
the terms of the series $\Delta s_{y}$, and in the other $(x \angle y)$, the terms of the series $\Delta d_{x}$.

Refer to the series $\Delta s_{y}$. We notice, first, that none of the values (with the exception of the last two) consist of more than three figures. The required multiples then can be easily formed by the aid of a small table of the multiples corresponding to the first nine natural numbers. Secondly, a good many of the values occur twice, and some of them oftener, so that the number of multiples to be formed will always be less than the number of values in the column to be construeted. And, thirdly, if the values be arranged once for all, in the order of their magnitude, with space between them for their differences, on a separate slip, similar to that already described, it is evident that then the multiples wanted may be very easily formed by the continuous addition of still smaller multiples.

Similar remarks apply to the other series, $\Delta d_{x}$, corresponding to the terms of which, also, multiples have to be formed. The formation in this case, however, is much easier. Only seven terms of the series consist of more than two figures; as many as twenty of them are zero; most of the others are frequently repeated, and of nearly the whole of these the constant difference is 5 . There are, in fact, in no case more than twenty-four distinct multiples to be formed. It is to be noted, moreover, in reference to this series, that a good many of its terms are negative. The multiples corresponding to these terms must consequently be subtracted instead of added; and this change of affection should be indicated in setting them down by prefixing the negative sign, or by writing them in red ink.

To return now to the example. The values formed, it will be borne in mind, have reference each to a single year only, and are consequently not those that are requisite to be tabulated. The values for tabulation are those having reference to the whole after lifetime at each age. These values obviously consist of the successive sums formed by continuous addition of the values formed as above, in which $x$ and $y$ have a common difference. The formation of a few of these final values, for the first six differences of $x$ and $y$, is shown on the opposite page.

This construction needs little explanation. The addends in the several columns will be found in the successive rows in the previous formation. The terms in the present formation, in which the values of $x$ and $y$ are interchanged, will be found oceupying corresponding positions in the two portions; and addition of any two of these 
1855.] Construction of Survivorship Assurance Tables.

\begin{tabular}{|c|c|c|c|c|c|c|}
\hline$x$ & $x-y=0$ & $x-y=1$ & $x-y=2$ & $x-y=3$ & $x-y=4$ & $x-y=5$ \\
\hline 104 & $\begin{array}{l}\cdot 0224420 \\
\cdot 1849220\end{array}$ & $\begin{array}{l}\cdot 0897680 \\
\cdot 3698440\end{array}$ & $\begin{array}{l}\cdot 1795360 \\
\cdot 5547660\end{array}$ & $\begin{array}{l}\cdot 2693040 \\
\cdot 7396880\end{array}$ & $\begin{array}{l}\cdot 3590720 \\
\cdot 9246100\end{array}$ & $\begin{array}{r}-4488400 \\
1 \cdot 1557625\end{array}$ \\
\hline 103 & $\begin{array}{l}-2073640 \\
-3809394\end{array}$ & $\begin{array}{l}\cdot 4596120 \\
.5714091\end{array}$ & $\begin{array}{l}7343020 \\
.7618788\end{array}$ & $\begin{array}{r}1.0089920 \\
.9523485\end{array}$ & $\begin{array}{l}1 \cdot 2836820 \\
1 \cdot 1904356\end{array}$ & $\begin{array}{l}1.6046025 \\
1.5237575\end{array}$ \\
\hline 102 & $\begin{array}{l}\cdot 5883034 \\
\cdot 5885513\end{array}$ & $\begin{array}{r}1.0310211 \\
77847351\end{array}$ & $\begin{array}{r}1 \cdot 4961808 \\
\cdot 9809189\end{array}$ & $\begin{array}{l}1.9613405 \\
1.2261486\end{array}$ & $\begin{array}{l}2 \cdot 4741176 \\
1 \cdot 5694702\end{array}$ & $\begin{array}{l}3 \cdot 1283600 \\
2 \cdot 0108837\end{array}$ \\
\hline 101 & $\begin{array}{r}1 \cdot 1768547 \\
\cdot 8082771\end{array}$ & $\begin{array}{l}1 \cdot 8157562 \\
1.0103464\end{array}$ & $\begin{array}{l}2 \cdot 4770997 \\
1 \cdot 2629330\end{array}$ & $\begin{array}{l}3 \cdot 1874891 \\
1 \cdot 6165542\end{array}$ & $\begin{array}{l}4 \cdot 0435878 \\
2 \cdot 0712101\end{array}$ & $\begin{array}{l}5 \cdot 1392437 \\
2 \cdot 6774179\end{array}$ \\
\hline 100 & $\begin{array}{l}1.9851318 \\
1 \cdot 0406568 \\
\end{array}$ & $\begin{array}{l}2 \cdot 8261026 \\
1.3008210\end{array}$ & $\begin{array}{l}3.7400327 \\
1.6650509\end{array}$ & $\begin{array}{l}4 \cdot 8040433 \\
2 \cdot 1333465\end{array}$ & $\begin{array}{l}6 \cdot 1147979 \\
2 \cdot 7577406\end{array}$ & $\begin{array}{l}7 \cdot 8166616 \\
3 \cdot 6422989 \\
\end{array}$ \\
\hline 99 & $\begin{array}{l}3 \cdot 0257886 \\
2 \cdot 0097684 \\
\end{array}$ & $\begin{array}{l}4 \cdot 1269236 \\
2 \cdot 5725036 \\
\end{array}$ & $\begin{array}{l}5 \cdot 4051836 \\
3 \cdot 2960202 \\
\end{array}$ & $\begin{array}{l}6 \cdot 9373898 \\
4 \cdot 260709 \mathrm{I}\end{array}$ & $\begin{array}{l}8 \cdot 8725385 \\
5 \cdot 6273516\end{array}$ & $\begin{array}{r}11 \cdot 4589605 \\
7.5567293 \\
\end{array}$ \\
\hline 98 & $\begin{array}{l}5 \cdot 0355570 \\
3 \cdot 5329050\end{array}$ & $\begin{array}{l}6 \cdot 6994272 \\
4 \cdot 5265345\end{array}$ & $\begin{array}{l}8.7011038 \\
5 \cdot 8513739\end{array}$ & $\begin{array}{r}11 \cdot 1980989 \\
7 \cdot 7282297\end{array}$ & $\begin{array}{l}14 \cdot 4998901 \\
10 \cdot 3779084\end{array}$ & $\begin{array}{l}19 \cdot 0156898 \\
14^{-2420232}\end{array}$ \\
\hline 97 & $\begin{array}{l}8 \cdot 5684620 \\
5 \cdot 8279131\end{array}$ & $\begin{array}{r}11 \cdot 2259617 \\
7 \cdot 5336438\end{array}$ & $\begin{array}{r}14 \cdot 5524777 \\
9 \cdot 9500956\end{array}$ & $\begin{array}{l}18 \cdot 9263286 \\
13 \cdot 3615569\end{array}$ & $\begin{array}{l}24 \cdot 8777985 \\
18 \cdot 3366047\end{array}$ & $\begin{array}{l}33 \cdot 2577130 \\
25.5859600\end{array}$ \\
\hline 96 & $\begin{array}{l}14 \cdot 3963751 \\
10 \cdot 8635143\end{array}$ & $\begin{array}{l}18 \cdot 7596055 \\
14-3480378\end{array}$ & $\begin{array}{l}24 \cdot 5025733 \\
19 \cdot 2673651\end{array}$ & $\begin{array}{l}32 \cdot 2878855 \\
26 * 4413840\end{array}$ & $\begin{array}{l}43 \cdot 2144032 \\
36 \cdot 8949544\end{array}$ & $\begin{array}{l}58 \cdot 8436730 \\
50 \cdot 6280763\end{array}$ \\
\hline 95 & $25-2598894$ & $33 \cdot 1076433$ & $43 \cdot 7699334$ & 58.7292695 & $80^{\circ} 1093576$ & $109 \cdot 4717493$ \\
\hline
\end{tabular}

$x<y$

\begin{tabular}{|c|c|c|c|c|c|c|}
\hline$y$ & $y-x=0$ & $y-x=1$ & $y-x=2$ & $y-x=3$ & $y-x=4$ & $y-x=5$ \\
\hline 104 & $\begin{array}{l}\cdot 0224420 \\
\cdot 1849220\end{array}$ & $\begin{array}{l}\cdot 0448840 \\
-1849220\end{array}$ & $\begin{array}{l}\cdot 0448840 \\
\cdot 1849220\end{array}$ & $\begin{array}{l}\cdot 0448840 \\
\cdot 1849220\end{array}$ & $\begin{array}{l}\cdot 0448840 \\
-1849220\end{array}$ & $\begin{array}{l}-0448840 \\
\cdot 2773830\end{array}$ \\
\hline 103 & $\begin{array}{l}2073640 \\
\cdot 3809394\end{array}$ & $\begin{array}{l}-2298060 \\
-3809394\end{array}$ & $\begin{array}{l}-2298060 \\
.3809394\end{array}$ & $\begin{array}{l}-2298060 \\
.3809394\end{array}$ & $\begin{array}{l}\cdot 2298060 \\
-5714091\end{array}$ & $\begin{array}{l}\cdot 3222670 \\
7618788\end{array}$ \\
\hline 102 & $\begin{array}{l}\cdot 5883034 \\
.5885513\end{array}$ & $\begin{array}{l}\cdot 6107454 \\
\cdot 5885513\end{array}$ & $\begin{array}{l}-6107454 \\
-5885513\end{array}$ & $\begin{array}{l}.6107454 \\
.8828270\end{array}$ & $\begin{array}{r}-8012151 \\
1 \cdot 1771027\end{array}$ & $\begin{array}{l}1 \cdot 0841458 \\
1 \cdot 4713784\end{array}$ \\
\hline 101 & $\begin{array}{r}1 \cdot 1768547 \\
\cdot 8082771\end{array}$ & $\begin{array}{r}I \cdot 1992967 \\
-8082771\end{array}$ & $\begin{array}{l}1 \cdot 1992967 \\
1-2124157\end{array}$ & $\begin{array}{l}1-4935724 \\
1.6165543\end{array}$ & $\begin{array}{l}1.9793178 \\
2 \cdot 0206929\end{array}$ & $\begin{array}{l}2 \cdot 5555242 \\
2 \cdot 8289700\end{array}$ \\
\hline 100 & $\begin{array}{l}1 \cdot 9851318 \\
1 \cdot 0406568\end{array}$ & $\begin{array}{l}2 \cdot 0075738 \\
1 \cdot 5609852\end{array}$ & $\begin{array}{l}2 \cdot 4117124 \\
20813136\end{array}$ & $\begin{array}{l}3 \cdot 1101267 \\
2 \cdot 6016420\end{array}$ & $\begin{array}{l}3-9990107 \\
3 \cdot 6422988\end{array}$ & $\begin{array}{l}5 \cdot 3844942 \\
5 \cdot 2032840\end{array}$ \\
\hline 99 & $\begin{array}{l}3 \cdot 0257886 \\
2 \cdot 0097684\end{array}$ & $\begin{array}{l}3 \cdot 5685590 \\
2 \cdot 6796912\end{array}$ & $\begin{array}{l}4 \cdot 4930260 \\
3 \cdot 3496140\end{array}$ & $\begin{array}{l}5 \cdot 7117687 \\
4 \cdot 6894596\end{array}$ & $\begin{array}{l}7 \cdot 6413095 \\
6 \cdot 6992280\end{array}$ & $\begin{array}{r}10 \cdot 5877782 \\
9 \cdot 3789193\end{array}$ \\
\hline 98 & $\begin{array}{l}5 \cdot 0355570 \\
3 \cdot 5329050\end{array}$ & $\begin{array}{l}6 \cdot 2482502 \\
4 \cdot 4161312\end{array}$ & $\begin{array}{l}7 \cdot 8426400 \\
6 \cdot 1825837\end{array}$ & $\begin{array}{r}10 \cdot 4012283 \\
8 \cdot 8322624\end{array}$ & $\begin{array}{l}14: 3405375 \\
12 \cdot 3651674\end{array}$ & $\begin{array}{l}19 \cdot 9666975 \\
18 \cdot 54775] 1\end{array}$ \\
\hline 97 & $\begin{array}{l}8 \cdot 5684620 \\
5 \cdot 8279131\end{array}$ & $\begin{array}{r}10 \cdot 6643814 \\
8 \cdot 1590783\end{array}$ & $\begin{array}{l}14 \cdot 0252237 \\
11 \cdot 6558262\end{array}$ & $\begin{array}{l}19 \cdot 2334907 \\
16 * 3181567\end{array}$ & $\begin{array}{l}26.7057049 \\
24-4772351\end{array}$ & $\begin{array}{l}38.5144486 \\
34 \cdot 9674787\end{array}$ \\
\hline 96 & $\begin{array}{l}14.3963751 \\
10.8635143\end{array}$ & $\begin{array}{l}18 \cdot 8234597 \\
15.5193062\end{array}$ & $\begin{array}{l}25.6810499 \\
21 \cdot 7270287\end{array}$ & $\begin{array}{l}35 \cdot 5516474 \\
32 \div 5905431\end{array}$ & $\begin{array}{l}51 \cdot 1829400 \\
46 \cdot 5579187\end{array}$ & $\begin{array}{l}73 \cdot 4819273 \\
57 \cdot 4214331\end{array}$ \\
\hline 95 & $25 \cdot 2598894$ & $34 \mathbf{3 4 2 7 6 5 9}$ & 47,4080786 & $68 \cdot 1421905$ & $97 \cdot 7408587$ & 130.9033604 \\
\hline
\end{tabular}


corresponding terms will give the $\mathbf{M}$ corresponding to the values of $x$ and $y$ that belonging to those terms. Thus-

$$
\mathrm{M}_{101.97}=\begin{array}{r}
4.0435878 \\
1.9783178
\end{array}
$$

To show the final arrangement of the terms now formed, I give the concluding portion of the table corresponding to difference of

\begin{tabular}{|c|c|c|c|c|c|c|}
\hline \multicolumn{2}{|c|}{ Ages. } & $\mathrm{D}$ & $\mathrm{N}$ & $\mathbf{E}$ & $\mathrm{F}$ & $\mathrm{M}$ \\
\hline 90 & 95 & 256.9646 & 3126071 & $109 \cdot 471749$ & 130.903360 & 240.375110 \\
\hline 91 & 96 & $141 \cdot 4307$ & $171 \cdot 17636$ & 58.843673 & $73 \cdot 481927$ & 132.325600 \\
\hline 92 & 97 & 76.75788 & $94 \cdot 41848$ & 332257713 & 38.514449 & $71 \cdot 772162$ \\
\hline 93 & 98 & 41.73244 & $52 \cdot 68604$ & $19 \cdot 015690$ & $19 \cdot 966698$ & $38 \cdot 982387$ \\
\hline 94 & 99 & $23 \cdot 58128$ & $29 \cdot 10476$ & $11 \cdot 458961$ & $10 \cdot 587778$ & $22 \cdot 046739$ \\
\hline 95 & 100 & $14 \cdot 048867$ & 15.05589 & $7 \cdot 816662$ & 5.384494 & $13 \cdot 201156$ \\
\hline 96 & 101 & $8 \cdot 133289$ & $6 \cdot 922603$ & $5 \cdot 139244$ & 2555524 & $7 \cdot 694768$ \\
\hline 97 & 102 & 4.414135 & $2 \cdot 508468$ & $3 \cdot 128360$ & 1.084146 & $4 \cdot 212506$ \\
\hline 98 & 103 & 1.999932 & .508536 & 1.604603 & 322267 & 1.926870 \\
\hline 99 & 104 & -508536 & .000000 & $\cdot 448840$ & $\cdot 044884$ & $\cdot 493724$ \\
\hline
\end{tabular}
ages five years, as it will appear when completed. The columns $\mathrm{D}$ and $\mathrm{N}$ are borrowed from Jones.

The new columns here are $\mathbf{E}$ and $\mathbf{F} ; \mathbf{M}$, which contains the sums of the corresponding terms in $\mathbf{E}$ and $\mathrm{F}$, being also now added for the first time to a joint life table. And it will by this time, I suppose, be sufficiently understood that the fundamental properties of these columns are that, taking any pair of the tabulated ages, say 95.100 ,

$\frac{\mathrm{E}_{95.100}}{\overline{\mathrm{D}}_{95.100}}=$ the present value of an assurance of $£ 1$ on $(100)$ against (95);

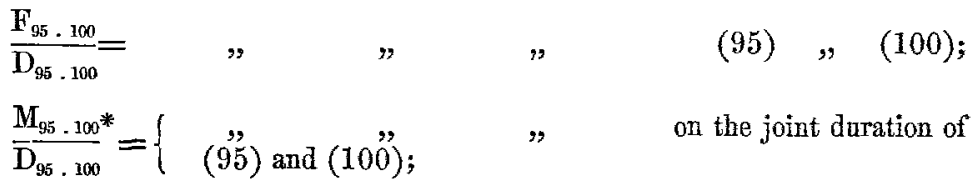
and the other properties, requisite for the formation of temporary, deferred, and intercepted assurances, necessarily follow from the possession of these. By the continuous summation of the terms in these columns, also, other columns may be formed, ad infinitum, which shall possess like properties in regard to assurances increasing from year to year.

* If $N_{94} 99$ take the place of $D_{95.100}$ in these expressions, they will denote the annual premiums for the same benefits, payable during the joint duration of $(95.100)$. 
If in the foregoing construction $v$ be made equal to unity (which leads to $r=0$, i.e., to the hypothesis of money bearing no interest), the construction will be much facilitated. The results of columns $\mathbf{E}$ and $\mathrm{F}$ will then indicate probabilities of survivorship, while column $M$ will become identical with column $D$, since the number of failures after a specified age is necessarily equal to the number alive at the same age.

\section{II.-Construction in Logarithms.}

Recurring to the symbolical expressions on page 110 for the leading terms of several adjoining columns belonging to the case $x>y$, namely,

$\begin{array}{cccc}x-y=0 & x-y=1 & x-y=2 & x-y=3 \\ d_{104} s_{104} v^{105}, & d_{104} s_{103} v^{105}, & d_{104} s_{102} v^{105}, & d_{104} s_{101} v^{105}, \\ d_{103} s_{103} v^{104}, & d_{103} s_{102} v^{104}, & d_{103} s_{101} v^{104}, & d_{103} s_{100} v^{104}, \\ d_{102} s_{102} v^{103}, & d_{102} s_{101} v^{103}, & d_{102} s_{100} v^{103}, & d_{102} s_{99} v^{103},\end{array}$

we have to examine now, not the differences, but the ratios of those terms. Take a column-the first. Here we have

$$
\frac{d_{103} s_{103} v^{104}}{d_{104} s_{104} v^{105}}=\frac{d_{103}}{d_{104}} \cdot \frac{s_{103}}{s_{104}}(1+r) ; \quad \frac{d_{102} s_{102} v^{103}}{d_{103} s_{103} v^{104}}=\frac{d_{102}}{d_{103}} \cdot \frac{s_{102}}{s_{103}}(1+r) ;
$$

and we should find similar expressions for the ratios in the other columns. It will thus appear that the addends by the use of which, setting out with the logarithms of the initial terms, we should form continuously the logarithms of the successive terms in each column, are

$(x-y=0), \Delta \log \cdot d_{104}+\Delta \log \cdot s_{104}+\log \cdot(1+r), \Delta \log \cdot d_{103}+\Delta \log \cdot s_{103}+\log .(1+r), \& \mathrm{c}$. $(x-y=1), \Delta \log . d_{104}+\Delta \log . s_{103}+\log .(1+r), \Delta \log . d_{103}+\Delta \log . s_{102}+\log .(1+r), \& c$. $(x-y=2), \Delta \log . d_{104}+\Delta \log \cdot s_{102}+\log .(1+r), \Delta \log . d_{103}+\Delta \log \cdot s_{101}+\log .(1+r), \& c$.

and so on. There is nothing formidable here. Additions of three lines will suffice, since the constant, log. $(1+r)$, can be combined once for all with the terms of one or other of the series $\Delta \log . d_{x}$ or $\Delta \log . s_{y}$. But I use this method only for verification. There is an easier method for the principal formation.

Examine the ratios in the several rows. From the first row we have-

$$
\frac{d_{104} s_{103} v^{105}}{d_{104} v_{104} v^{105}}=\frac{s_{103}}{s_{104}} ; \frac{d_{104} s_{102} v^{105}}{d_{104} s_{103} v^{105}}=\frac{s_{102}}{s_{103}} ; \frac{d_{104^{s} s_{100}} v^{105}}{d_{104} s_{102} v^{105}}=\frac{s_{101}}{s_{102}}, \& \mathbf{c}
$$


from the second--

$$
\frac{d_{103} s_{102} v^{104}}{d_{103} s_{103} v^{104}}=\frac{s_{102}}{s_{103}} ; \frac{d_{103} s_{101} v^{104}}{d_{103} s_{102} v^{104}}=\frac{s_{101}}{s_{102}} ; \frac{d_{103} s_{100} v^{104}}{d_{103} s_{101} v^{104}}=\frac{s_{100}}{s_{101}}, \& \mathrm{c} .
$$

and so on. Hence, taking the logarithms of these ratios, the addends for the continuous formation of the logarithms of the values occupying the several rows will be the terms of the series $\Delta \log . s_{y}$.

A like procedure to that employed above will show, that in the case $x \angle y$ the addends for the formation in columns are series of terms of the same form as those obtained for the case $x>y$, the only difference being that the terms of the series $\Delta \log . d_{x}$ and $\Delta \log . s_{y}$ are interchanged; and that for the formation in rows the addends are the terms of the series $\Delta \log$. $d_{x}$.

The following table contains the portions of the several auxiliary series here requisite, which come into operation in the examples to be presently given.

\begin{tabular}{|c|c|c|c|c|c|c|}
\hline$x \& y$ & Log. $s_{y}$ & $\Delta \log . s_{y}$ & $\nabla \log . s_{y}$ & $\log . d_{x}$ & $\Delta \log . d_{x}$ & $\nabla \log . d_{x}$ \\
\hline 104 & 0.0000000 & 6020600 & 6148972 & $\overline{\mathrm{I}} 6989700$ & 3010300 & 3138672 \\
\hline 103 & $\cdot 6020600$ & 3010300 & 3138672 & 0.0000000 & 0000000 & 0128372 \\
\hline 102 & $\cdot 9030900$ & 1760912 & 1889285 & -0000000 & 0000000 & 0128373 \\
\hline 101 & $1 \cdot 0791812$ & 1249388 & 1377760 & -0000000 & 0000000 & 0128372 \\
\hline 100 & 2041200 & 0969100 & 1097472 & $\cdot 0000000$ & 0000000 & 0128372 \\
\hline 99 & $\cdot 3010300$ & 0969100 & 1097472 & -0000000 & 1760913 & 1889285 \\
\hline 98 & $\cdot 3979400$ & 1072100 & 1200473 & $\cdot 1760913$ & 1249387 & 3377760 \\
\hline 97 & -5051500 & 1076339 & 1204711 & $\cdot 3010300$ & 0969100 & 1097472 \\
\hline 96 & $\cdot 6127839$ & 1114920 & 1243292 & $\cdot 3979400$ & 1461280 & 1589652 \\
\hline 95 & 7242759 & 1208221 & 1336593 & $\cdot 5440680$ & 1549020 & 1677392 \\
\hline 94 & $\cdot 8450980$ & 1280299 & 1408672 & $\cdot 6989700$ & 1461280 & 1589653 \\
\hline 93 & -9731279 & 1374618 & 1502990 & .8450980 & 1760913 & 1889285 \\
\hline 92 & $2 \cdot 1105897$ & I 446828 & 1575200 & $1 \cdot 0211893$ & 1549020 & 1677392 \\
\hline 91 & $\cdot 2552725$ & 1374245 & 1502617 & $\cdot 1760213$ & $09] 0804$ & 1039176 \\
\hline 90 & $\cdot 3926970$ & 1165055 & 1293428 & -2671717 & 0228629 & 0357002 \\
\hline 89 & $\cdot 5092025$ & 1067476 & 1195848 & $\cdot 2900346$ & 1165056 & 1293428 \\
\hline 88 & .6159501 & 1066838 & 1195210 & .4065402 & 0986098 & 1114470 \\
\hline 87 & $\cdot 7226339$ & 0988796 & 1117168 & -5051500 & 0450784 & 0579156 \\
\hline 86 & 8215135 & 0880425 & 1008798 & $\cdot 5502284$ & 0408362 & 0536735 \\
\hline 85 & -9095560 & 0790030 & 0918402 & -5910646 & 0321847 & 0450219 \\
\hline 84 & $• 9885590$ & & & $\cdot 6232493$ & & \\
\hline
\end{tabular}

The formation of this table is sufficiently obvious,* with the exception of the columns headed $\nabla \log . s_{y}$ and $\nabla \log . d_{x}$. The values in these columns are the corresponding values in the immediately preceding columns respectively, increased by log. $(1+r)=0128372$. The succeeding figures of this constant logarithm being 247 , or say 25 , the requisite correction is made by

* $\Delta$ log. $s_{y}$ and $\Delta$ log. $d_{x}$ must not be confounded with log. $\Delta s_{y}$ and log. $\Delta d_{x}$. The difference of the logarithm of a number is by no means the same thing as the logarithm of the difference of that number. 
increasing the third and every fourth following term of the series in which this logarithm enters by a unit in the last place. But for the necessity for this correction, it would suffice to combine the constant logarithm with the terms of only one of the series $\Delta \log . s_{y}, \Delta \log . d_{x}$. The corrections would in such case fall in the proper places in the values formed for verification, only when the differences of age are of the form $4 n$.

The initial and verification values are formed as follows:-

Initial and Verification Values.

\begin{tabular}{|c|c|c|c|c|c|c|c|}
\hline \multicolumn{4}{|c|}{$x>y$} & \multicolumn{4}{|c|}{$x \angle y$} \\
\hline \multicolumn{2}{|c|}{$x-y=0$} & \multicolumn{2}{|c|}{$x-y=I 3$} & \multicolumn{2}{|c|}{$y-x=0$} & \multicolumn{2}{|c|}{$y-x=13$} \\
\hline $\begin{array}{l}\text { Log. } v^{105} \\
\Rightarrow d_{104} \\
\Rightarrow s_{104}\end{array}$ & $\begin{array}{l}6520914 \\
6989700 \\
0000000\end{array}$ & $\begin{array}{c}\log \cdot v^{105} \\
\Rightarrow d_{104} \\
\Rightarrow s_{91}\end{array}$ & $\begin{array}{l}6520914 \\
6989700 \\
2552725\end{array}$ & $\begin{array}{l}\text { Log. } v^{105} \\
\Rightarrow \quad s_{104} \\
\Rightarrow d_{104}\end{array}$ & $\begin{array}{l}6520914 \\
0000000 \\
6989700\end{array}$ & $\begin{array}{c}\log \cdot v^{105} \\
\Rightarrow s_{104} \\
\Rightarrow d_{91}\end{array}$ & $\begin{array}{l}6520914 \\
0000000 \\
1760913\end{array}$ \\
\hline $\begin{array}{l}104.104 \\
\nabla \log . d_{104} \\
\Delta \geqslant s_{104}\end{array}$ & \begin{tabular}{|l|}
3510614 \\
3138672 \\
6020600
\end{tabular} & $\begin{array}{c}104.91 \\
\nabla \log . d_{104} \\
\Delta \% s_{91}\end{array}$ & $\begin{array}{l}6063339 \\
3138672 \\
1374245\end{array}$ & $\begin{array}{l}104.104 \\
\nabla \log \cdot s_{104} \\
\Delta \quad \# d_{104}\end{array}$ & $\begin{array}{l}3510614 \\
6148972 \\
3010300\end{array}$ & $\begin{array}{c}91.104 \\
\nabla \log . s_{104} \\
\Delta \Rightarrow d_{91}\end{array}$ & $\begin{array}{l}8281827 \\
6148972 \\
0910804\end{array}$ \\
\hline $\begin{array}{l}103.103 \\
\nabla \log . d_{103} \\
\Delta \# \text { slo3 }^{2}\end{array}$ & $\begin{array}{r}2669886 \\
0128372 \\
3010300\end{array}$ & $\begin{array}{c}103.90 \\
\nabla \log . d_{103} \\
\Delta \% s_{90}\end{array}$ & $\begin{array}{l}0576256 \\
0128372 \\
1165055\end{array}$ & $\begin{array}{c}103.103 \\
\nabla \log . s_{103} \\
\Delta \quad \% d_{103}\end{array}$ & $\begin{array}{l}2669885 \\
3138672 \\
0000000\end{array}$ & $\begin{array}{c}90.103 \\
\nabla \log . s_{103} \\
\Delta \Rightarrow d_{90}\end{array}$ & $\begin{array}{l}5341603 \\
3138672 \\
0228629\end{array}$ \\
\hline $\begin{array}{c}102.102 \\
\nabla \log . d_{102} \\
\Delta, s_{102}\end{array}$ & $\begin{array}{l}5808558 \\
0128373 \\
1760912\end{array}$ & 102.89 & $\begin{array}{l}1869683 \\
0128373 \\
1067476\end{array}$ & 102.102 & $\begin{array}{l}5808558 \\
1889285 \\
0000000\end{array}$ & 89.102 & $\begin{array}{l}8708904 \\
1889285 \\
1165056\end{array}$ \\
\hline $\begin{array}{l}101.101 \\
\nabla \log . d_{101} \\
\Delta \# s_{101}\end{array}$ & $\begin{array}{l}7697843 \\
0128372 \\
1249388\end{array}$ & 101.88 & $\begin{array}{l}3065532 \\
0128372 \\
1066838\end{array}$ & 101.101 & $\begin{array}{l}7697843 \\
1377760 \\
0000000\end{array}$ & 88.101 & $\begin{array}{l}1763245 \\
1377760 \\
0986098\end{array}$ \\
\hline $\begin{array}{c}100.100 \\
\nabla \log . d_{100} \\
\Delta \Rightarrow s_{100}\end{array}$ & $\begin{array}{l}9075603 \\
0128372 \\
0969100\end{array}$ & 100.87 & $\begin{array}{l}4260742 \\
0128372 \\
0988796\end{array}$ & 100.100 & $\begin{array}{l}9075603 \\
1097472 \\
0000000\end{array}$ & 87.100 & $\begin{array}{l}4127103 \\
1097472 \\
0450784\end{array}$ \\
\hline 99.99 & 0173075 & 99.86 & 5377910 & 99.99 & 0173075 & 86.99 & 56753.59 \\
\hline & & Verifice & tion of $t$ & above & Values. & & \\
\hline $\begin{array}{c}\text { Log. } v^{100} \\
\Rightarrow \quad d_{99} \\
\Rightarrow \quad s_{99}\end{array}$ & $\left|\begin{array}{l}7162775 \\
0000000 \\
3010300\end{array}\right|$ & $\begin{array}{c}\text { Log. } v^{100} \\
\Rightarrow \quad d_{39} \\
\Rightarrow \quad 886\end{array}$ & $\mid \begin{array}{l}7162775 \\
0000000 \\
8215135\end{array}$ & $\begin{array}{cc}\log _{*} v^{100} \\
\Rightarrow & s_{99} \\
\Rightarrow & d_{99}\end{array}$ & $\left|\begin{array}{l}7162775 \\
3010300 \\
0000000\end{array}\right|$ & $\begin{array}{cc}\text { Log. } w^{100} \\
\Rightarrow s_{99} \\
\Rightarrow d_{86}\end{array}$ & $\mid \begin{array}{l}7162775 \\
3010300 \\
5502284\end{array}$ \\
\hline & 0173075 & & 5377910 & & 0173075 & & 5675359 \\
\hline
\end{tabular}

The initial values are, of course, the same in both compartments. I have, nevertheless, formed them separately for the sake of symmetry, and to show more distinctly how the addend series vary in passing from column to column.

I now introduce an example of the actual formation :- 
$x>y$

\begin{tabular}{|c|c|c|c|c|c|c|}
\hline$x-y$ & $x=104$ & $x=103$ & $x=102$ & $x=101$ & $x=100$ & $x=99$ \\
\hline 0 & 3510614 & 2669886 & 5808558 & 7697843 & 9075603 & 0173075 \\
& 6020600 & 3010300 & 1760912 & 1249388 & 0969100 & 0969100 \\
\hline 1 & 9531214 & 5680186 & 7509470 & 8947231 & 0044703 & 1142175 \\
& 3010300 & 1760912 & 1249388 & 0969100 & 0969100 & 1072100 \\
\hline 2 & 2541514 & 7441098 & 8818858 & 9916331 & 1013803 & 2214275 \\
& 1760912 & 1249388 & 0969100 & 0969100 & 1072100 & 1076339 \\
\hline 3 & 4302426 & 8690486 & 9787958 & 0885431 & 2085903 & 3290614 \\
& 1249388 & 0969100 & 0969100 & 1072100 & 1076339 & 1114920 \\
\hline 4 & 5551814 & 9659586 & 0757058 & 1957531 & 3162242 & 4405534 \\
& 0969100 & 0969100 & 1072100 & 1076339 & 1114920 & 1208221 \\
\hline 5 & 6520914 & 0628686 & 1829158 & 3033870 & 4277162 & 5613755 \\
& 0969100 & 1072100 & 1076339 & 1114920 & 1208231 & 1280299 \\
\hline 6 & 7490014 & 1700786 & 2905497 & 4148790 & 5485383 & 6894054 \\
& 1072100 & 1076339 & 1114920 & 1208221 & 1280299 & 1374618 \\
\hline 7 & 8562114 & 2777125 & 4020417 & 5357011 & 6765632 & 8268672 \\
& 1076339 & 1114920 & 1208221 & 1280299 & 1374618 & 1446828 \\
\hline 8 & 9638453 & 3892045 & 5228638 & 6637310 & 8140300 & 9715500 \\
& 1114920 & 1208221 & 1280299 & 1374618 & 1446828 & 1374245 \\
\hline 9 & 0753373 & 5100266 & 6508937 & 8011928 & 9587128 & 1089745 \\
& 1208221 & 1280299 & 1374618 & 1446828 & 1374245 & 1165055 \\
\hline 10 & 1961594 & 6380565 & 7883555 & 9458756 & 0961373 & 2254800 \\
& 1280299 & 1374618 & 1446828 & 1374245 & 1165055 & 1067476 \\
\hline 11 & 3241893 & 7755183 & 9330383 & 0833001 & 2126428 & 3322276 \\
& 1374618 & 1446828 & 1374245 & 165055 & 1067476 & 1066838 \\
\hline $\mathbf{1 2}$ & 4616511 & 9202011 & 0704628 & 1998056 & 3193904 & 4389114 \\
& 1446828 & 1374245 & 1165055 & 1067476 & 1066838 & 0988796 \\
\hline $\mathbf{1 3}$ & 6063339 & 0576256 & 1869683 & 3065532 & 4260742 & 5377910 \\
\hline
\end{tabular}

$x<y$

\begin{tabular}{|c|c|c|c|c|c|c|}
\hline$y-x$ & $y=104$ & $y=103$ & $y=102$ & $y=101$ & $y=100$ & $y=99$ \\
\hline 0 & $\begin{array}{l}3510614 \\
3010300\end{array}$ & $\begin{array}{r}2669886 \\
0\end{array}$ & $\begin{array}{r}5808558 \\
0\end{array}$ & $\begin{array}{r}7697843 \\
0\end{array}$ & $\begin{array}{r}9075603 \\
0\end{array}$ & $\begin{array}{l}0173075 \\
1760913\end{array}$ \\
\hline 1 & $\begin{array}{r}6520914 \\
0\end{array}$ & $\begin{array}{r}2669886 \\
0\end{array}$ & $\begin{array}{r}5808558 \\
0\end{array}$ & $\begin{array}{r}7697843 \\
0\end{array}$ & $\begin{array}{l}9075608 \\
1760913\end{array}$ & $\begin{array}{l}1933988 \\
1249387\end{array}$ \\
\hline 2 & $\begin{array}{r}6520914 \\
0\end{array}$ & $\begin{array}{r}2669886 \\
0\end{array}$ & $\begin{array}{r}5808558 \\
0\end{array}$ & $\begin{array}{l}7697843 \\
1760913\end{array}$ & $\begin{array}{l}0836516 \\
1249387\end{array}$ & $\begin{array}{l}3183375 \\
0969100\end{array}$ \\
\hline 3 & $\begin{array}{r}6520914 \\
0\end{array}$ & $\begin{array}{r}2669886 \\
0\end{array}$ & $\begin{array}{l}5808558 \\
1760913\end{array}$ & $\begin{array}{l}9458756 \\
1249387\end{array}$ & $\begin{array}{l}2085903 \\
0969100\end{array}$ & $\begin{array}{l}4152475 \\
1461280\end{array}$ \\
\hline 4 & $\begin{array}{r}6520914 \\
0\end{array}$ & $\begin{array}{l}2669886 \\
1760913\end{array}$ & $\begin{array}{l}7569471 \\
1249387\end{array}$ & $\begin{array}{l}0708143 \\
0969100\end{array}$ & $\begin{array}{l}3055003 \\
1461280\end{array}$ & $\begin{array}{l}5613755 \\
1549020\end{array}$ \\
\hline 5 & $\begin{array}{l}6520914 \\
1760913\end{array}$ & $\begin{array}{l}4430799 \\
1249387\end{array}$ & $\begin{array}{l}8818858 \\
0969100\end{array}$ & $\begin{array}{l}1677243 \\
1461280\end{array}$ & $\begin{array}{l}4516283 \\
1549020\end{array}$ & $\begin{array}{l}7162775 \\
1461280\end{array}$ \\
\hline 6 & $\begin{array}{l}8281827 \\
1249387\end{array}$ & $\begin{array}{l}5680186 \\
0969100\end{array}$ & $\begin{array}{l}9787958 \\
1461280\end{array}$ & $\begin{array}{l}3138523 \\
1549020\end{array}$ & $\begin{array}{l}6065303 \\
1461280\end{array}$ & $\begin{array}{l}8624055 \\
1760913\end{array}$ \\
\hline 7 & $\begin{array}{l}9531214 \\
0969100\end{array}$ & $\begin{array}{l}6649286 \\
1461280\end{array}$ & $\begin{array}{l}1249238 \\
1549020\end{array}$ & $\begin{array}{l}4687543 \\
1461280\end{array}$ & $\begin{array}{l}7526583 \\
1760913\end{array}$ & $\begin{array}{l}0381968 \\
1549020\end{array}$ \\
\hline 8 & $\begin{array}{l}0500314 \\
1461280\end{array}$ & $\begin{array}{l}8110566 \\
1549020\end{array}$ & $\begin{array}{l}2798258 \\
1461280\end{array}$ & $\begin{array}{l}6148823 \\
1760913\end{array}$ & $\begin{array}{l}9287496 \\
1549020\end{array}$ & $\begin{array}{l}1938988 \\
0910804\end{array}$ \\
\hline 9 & $\begin{array}{l}1961594 \\
1549020\end{array}$ & $\begin{array}{l}9659586 \\
1461280\end{array}$ & $\begin{array}{l}4259538 \\
1760913\end{array}$ & $\begin{array}{l}7909736 \\
1549020\end{array}$ & $\begin{array}{l}0836516 \\
0910804\end{array}$ & $\begin{array}{l}2844792 \\
0228629\end{array}$ \\
\hline 10 & $\begin{array}{l}3510614 \\
1461280\end{array}$ & $\begin{array}{l}1120866 \\
1760913\end{array}$ & $\begin{array}{l}6020451 \\
1549020\end{array}$ & $\begin{array}{l}9458756 \\
0910804\end{array}$ & $\begin{array}{l}7747320 \\
0228629\end{array}$ & $\begin{array}{l}3073421 \\
1165056\end{array}$ \\
\hline II & $\begin{array}{l}4971894 \\
1760913\end{array}$ & $\begin{array}{r}2881779 \\
1549020\end{array}$ & $\begin{array}{l}7569471 \\
0910804\end{array}$ & $\begin{array}{l}0869560 \\
0228629\end{array}$ & $\begin{array}{l}1975949 \\
1165056\end{array}$ & $\begin{array}{l}4238477 \\
0986098\end{array}$ \\
\hline 12 & $\begin{array}{l}6732807 \\
1549020\end{array}$ & $\begin{array}{l}4430799 \\
0910804\end{array}$ & $\begin{array}{l}8480275 \\
0228629\end{array}$ & $\begin{array}{l}0598189 \\
1165056\end{array}$ & $\begin{array}{l}3141005 \\
0986098\end{array}$ & $\begin{array}{l}5224575 \\
0450784\end{array}$ \\
\hline 13 & 8281827 & 5341603 & 8708904 & 1763245 & 4127103 & 5675359 \\
\hline
\end{tabular}


After what has been said, this example seems to require but little explanation. The arrangement of the values is precisely the same as in the preceding formation in numbers. In the first compartment $x$ is constant in each column, and in the second $y$ is constant, while in both the differences of age are constant in the several rows. The values here formed are consequently the logarithms of the values occupying corresponding positions in the preceding formation. In practice it will be proper to leave the alternate columns unoccupied, to receive the natural numbers, which it is unnecessary here to take out, since, as just mentioned, we already have them in the first formation.

Refer to either portion of the present example-say the first. The addends in the several columns are the successive terms of the same series $\left(\Delta \log . s_{y}\right)$, commencing in each column with the term immediately following that with which a commencement was made in the preceding column. Each term consequently may be traced, from its occurrence in the first column, in a diagonally ascending line, till it appears for the last time in the first row. It is comparatively easy then, when the addends have been properly inserted in the first column, to insert them throughout, since a single reference for each value will suffice for every occurrence of that value on the same opening of the paper made use of. But the labour of writing the addends may be spared by writing them once for all upon one or more perforated cards of the form here shown.

The manner of using this card will be obvious from comparison of it with the first portion of the example just given. For the first column it will be placed with the first opening over the initial value in that column. Continuous addition then will, it is apparent, produce precisely the same values as already appear in the column in question. To form the second column, the card will be placed so that the initial value in that column shall appear through the second opening, opposite 103, and continuous addition will, as before, produce the required values. To make this more clear,

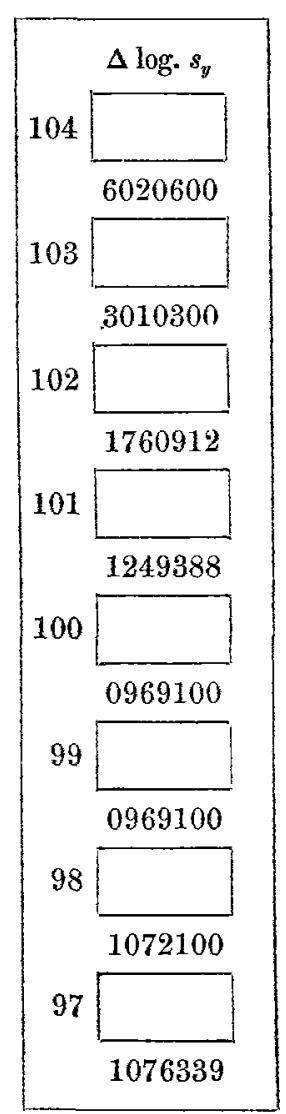


the card is here shown in three different positions, adapted to the formation of the leading terms of the first three columns.
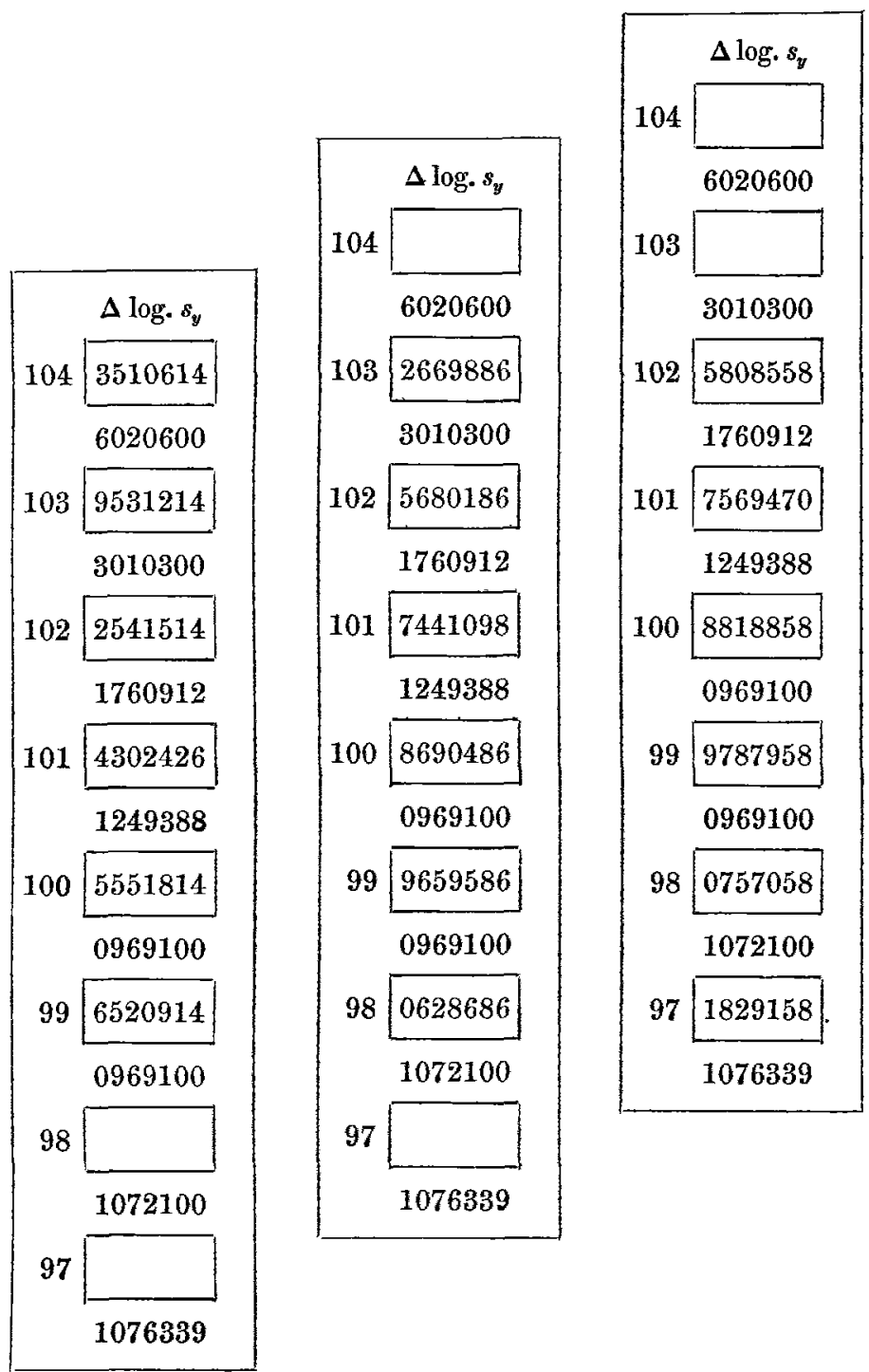

In a previous part of this paper I intimated my preference for the first of the two methods of construction that have now been described. The reason of this preference may be now briefly stated. It is simply this-that when the method in question is 
employed we have the benefit of a continuous process, and consequently the power of thorough verification, up to a later stage than when the logarithmic method is made use of. By the first method we form continuously the actual values of the functions, of which, by the other method, we form only the logarithms; and as the operation of taking out the numbers corresponding to these logarithms is one to which an infallible check cannot be applied, it seems to follow that we have the greatest security against error by employing the method of construction in numbers. It is true that this method is attended with a little more labour than the other; but, were the additional labour very much more than it is, I should consider it amply compensated by the advantage in regard to security against error which, as we have just seen, this method possesses.

Another distinction between the two methods deserves to be mentioned. When the logarithnic method is employed we can obtain no more than seven figures in the several results. Seven figures may or may not be sufficient. On this point different computers will entertain different views. Those who desire a greater number, however, or to ensure greater accuracy with the same number, can have their desire gratified to the fullest extent by employing the method of construction in numbers. The number of figures that may be obtained true by this method is, for all practicable purposes, unlimited.

And now, before I close, I would direct attention to a mechanieal aid, the use of which imparts an almost magical facility to the most complex and extensive computations, and in the absence of which even the best devised methods of applying formula at all complex, or requiring the employment of many figures, become exceedingly perplexing and irksome. I refer to the employment of paper, ruled in squares, each square being adapted to receive a single figure. By this means not only does each figure necessarily fall in its proper place, and so facilitate subsequent proceedings, but values that occur periodically, and have to be worked up to, as it were, in the course of continuous or other operations, can be inserted in their places in the outset, so as to avoid all necessity for interruption in the work. But one must try this paper to be able fully to appreciate its great advantages, and the facilities it affords. I believe I am warranted in saying, that by the employment of it in such operations as have been described in the present paper, the labour that would otherwise be necessary will be found to be reduced one half, while accuracy will be most materially 
promoted. The paper may be obtained by order of any stationer. That which I use (foolscap) has about 70 horizontal lines and 46 vertical lines on a page.

I am quite aware that this paper is known to and used by a good many actuaries, as well as in astronomical computations; but I have recently had occasion to become acquainted with so many instances in which it is not known, that $I$ believe $I$ shall be doing good service in thus prominently directing attention to its advantages.

I have now finished. I am quite prepared to learn that the practised computer, whatever opinion he may entertain of the methods $I$ have endeavoured to develope, will think that $I$ have been unnecessarily minute in my details as to their application. I admit it. For him I have gone into unnecessary detail. But I have had chiefly in view the younger members of the Institute, whom I would fain stimulate to enter upon the exercise of the construction of tables, and $I$ have been anxious to remove everything that might prove an obstruction in their way. If two, three, or four of our younger members would unite for the construction of a complete set of tables of the kind now described, the labour would be comparatively light; and, besides the benefit they would thus confer on the Profession generally, I feel very sure that, at the conclusion of their task, they would be ready to acknowledge that the exercise had been the most beneficial to themselves of any they ever entered upon. They would find they had acquired such an intimate acquaintance with the structure and properties of the tables, that they could apply them to practical purposes with a facility and confidence which without this preparation long experience only could have imparted. I should be glad to afford, to any of our friends disposed to act on this recommendation, all the assistance in my power in the way of information or suggestion.

In conclusion, I think it necessary to mention that the methods developed in the foregoing paper are identical in principle with methods $I$ have elsewhere described for like purposes. 